\title{
Rain, River and Religion A Study of Negotiating Identity of Bakumpai People in Kalimantan, Indonesia
}

\section{Setia Budhi. Ph. D.}

The Study Program of Sociology, The Faculty of Social and Political Sciences, Lambung Mangkurat University, South Kalimantan, Indonesia

Correspondence Author: Setia Budhi. Ph. D., The Study Program of Sociology, The Faculty of Social and Political Sciences, Lambung Mangkurat University, South Kalimantan, Indonesia

E-mail: sbudhi04@gmail.com

Received date: 12 June 2018, Accepted date: 4 September 2018, Online date: 13 September 2018

Copyright: (C) 2018 Setia Budhi. Ph. D., This is an open-access article distributed under the terms of the Creative Commons Attribution License, which permits unrestricted use, distribution, and reproduction in any medium, provided the original author and source are credited.

\begin{abstract}
Ethnographic study that related communcal identities in Kalimantan gave important understanding that customary communities, believes and local languages were interrelated. Scharer (1963) classified Dayak Baroto community as Ngaju. The term Ngaju in the local languate meant "toward upper course". Additionally, some used the term "Oloh Ngajus" to identify the communities that differed themselves from "Oloh TUmbang" representing the community of Dayak living in the area alongside estuary. The Olong Tumbang was the areas alongside the estuary of Barito River in which Bakumpai people lived. Using ethnographic approach, data were collected in the area of Barito, Samba and Long Iram Rivers. The data of the narration of the life of Bakumpai people and their identity were collected in the period of August 2015 to June 1016. the study found the religious identify of Bakumpai people in the context of Dayak and Islam in South Kalimantan and Central Kalimantan. Bakumpai people converted to Islam did not automatically leave their Dayak identity. They did not change their customary and cultural identity as the case of other communities of Dayak in Kalimantan who changed their identity into Malay (Tame Melayo, Basalam). The social structure of the people in the past could not instantly be changed into Malay social structure. The issue of customary identity as raised in the study has been discussed by researchers. Dayak was not compatible with Islam. However, Bakumpai people proudly acknowledged that they were part of Malay of the descendants of Ngaju.
\end{abstract}

Key words: Bakumpai People, Negotiating Identity

\section{INTRODUCTION}

Bakumpai people lived in some areas of Long Iram in East Kalimantan and Tumbang Samba in Central Kalimantan and Kampung Ulu Benteng in South Kalimantan. They represented an ethnic community that hase been developing till $19^{\text {th }}$ century. There were many opinions of the relationship and the survival and the development of the ethnic community among other ethnics and believes. It was well-understood that the Bakumpai people had a very good adaptability to their living environment. They migrated from the upper course area of Barito Hulu of Central Kalimantal. It confirmed the hypothesis that Barito War in 1869 was the reason for them to look for more safe living areas and they crossed eastward to Mahakam River and a part of them migrated westward to Tumbang Samba areas of Katingan River.

Who were actually Bakumpai people? It was a very interesting question. There were many opinions among researchers and there was not any agreement on the origin of the people. There were three different opinions of the origin of Bakumpai people. They were historical difference of the movement of the people to other areas in Kalimantan such as in Long Iram kampong alongside of Mahakam River of East Kalimantan, Central Kalimantan and South Kalimantan. The first opinion suggested that Bakumpai people originated from inland Dayak or mountain people, while the second opinion suggested that they originated from coastal areas and the third opinion referred to the word Bakumpai.

Cultural and identity globalization was translocal in nature (Pieterse, 1995). The culture and the identity could not be understood in local perspective, but it was necessary to conceptualize them in term of journey. The concept included culture and people that were in constant journey from one place to another as Clifford (1992) said that culture was sites of criss-crossing travellers. The idea of unstability of culture and identity in globalization brought us to the understanding that culture and identity were always the melting and mixing pots of various cultures and identities. It was what so-called culture and identity hybridity in which established borders of culture became blurred and unstable. It was in this context that we should put the emphasis on creolization.

In Imagined Communities: Reflections on the Origins and Spread of Nationalism (1983), Ben Anderson suggested that a nation was a national imaginary community and identity. It was a construct created through symbols and rituals related to administrative category and territory. According to him, national language and time and spatial awareness were a construct created by communication facilities. He described that the production of newspapers and books, for example, established linguistic standard that subsequently set the condition for the emergence of national awareness. The criticism of Anderson's opinion was that he considered language as stable. He put too much emphasis on homogeneous aspects, unity, and the strength of national feeling over difference in class, gender and ethnicity and did not see that the difference in context and interaction areas resulted in different and special identities.

The instability of language according to Homi Bhabha (1994) forced us not to consider culture and identity as constant ethnicity, but as constantly changing ethnicity. Anderson's opinion was not sufficient to understand how culture and identity were formed in a globalization. Globalization represented a very wide space for identity construction, artifacts/symbols exchange and easy interspatial movement and combined with the development of communication technology it enabled easy mixing and melting of cultures.

Homi Bhabha (1994) described mimicry concept as imitating/adapting process of various cultural elements. According to him, the mimicry was not indicative of the dependence of the colonized on the colonizer, the dependence of the color-skinned on the white, but imitator with ambivalence in the imitating 
Citation: Setia Budhi. Rain, River and Religion A Study of Negotiating Identity of Bakumpai People in Kalimantan, Indonesia. Australian Journal of Basic and Applied Sciences, 12(9): 26-30. DOI: 10.22587/ajbas.2018.12.9.4

process. It took place because the mimicry always indicated improper meaning that was put on the wrong place. It was imitation, while at the same time it was also subversion. Therefore, it could be considered as a strategy against domination. Just as camouflage it was ambivalent in nature, meaning that it perpetuated, while at the same time it also negated the domination. It was the basis of a hybrid identity.

In this context the question was then if the category of the identity of Bakumpai people could be considered as mimicry or if their identity in many aspects could be categorized as non-ambivalence and even consistent with the single meaning as Dayak people. At least, Bakumpai people were able to maintain their language and culture as Oloh Itah that related to linguistic, cultural and belief unity.

\section{Methodology:}

It was a qualitative study that used some interpretations of the religious experience and the identity of Bakumpai people. It took long time to describe one of the ethnographic angles of Bakumpai people. Information was gathered using informal conversation and in-depth and structured interview with anumber of informants. The interview began with familial relationship and then particular topics such as custom and ceremonies. It was recorded in the form of the narration of experiences and it was interpreted in the context of the identity of Bakumpai people in the location of the study.

The narration of the past experience helped understand the ethnical dynamics and its time and spatial impacts. Observation method helped contextualize cases and general information related to the problem of the study. The observation was conducted by directly observing customary ceremonies and religious activities in mosques and musholla to understand the customary and cultural practices. Tentative guideline was used to answer the question of the study related to the relevant issues. However, during in-field study there were new emerging paths and the paths were included in the interviews. Primary data were collected through the in-field study, while the secondary information was gathered from archives, reports, and newspapers.

Reconstruction of ethnical identity included age, education, social-economic status, gender and beliefs that were identified among key informants. The objective of the use of the key informants was to maximize the difference in the resulting responses for data heterogeneity.

Data analysis was made by first transcribing the recorded data. The interview has been recorded in Bakumpai. The interview results were saved in flashdisk. The interview results were then translated into Indonesian. The data were analyzed using qualitative analysis method. The analysis caught the information to construct reality just the way it was in the perspective of Bakumpai people of the social environment in which they lived considering the theme and the concept that seemed to correlate to the world of Bakumapi people.

\section{Bakumpai People: Settlements alongside Rivers.}

Ulu Benteng kampong was situated alongside Barito River. All of the houses in the kampong were constructed using timbers and shingles made of hard wood as roofs. During in-field study the majority of newly constructed houses were situated in south area of the kampong. It proved that the site of the settlement in the kampong gradually changed, meaning that the location of the kampong did not change in the last five years.

The settlement areas were always situated alongside Barito River based on practical consideration that the villagers could easily fulfill their daily requirements. The Ulu Benteng kampong was also situated alongside the river for ecological reason. The location of the kampong alongside the river implicated that Bakumpai people were also considered as Barito people. The name Ulu Benteng consisted of the words Ulu or Hulu and Benteng. Bentent represented colonial building that served the function of fortress, while Hulu was indicative of the location of the kampong in the upper course of the river.

The Ulu Benteng kampong was situated in agricultural lowland. Therefore, the villagers were highly dependent of the resources of Barito River for their agricultural system. Considering the location of the location of the kampong alongside Barito River, it was 5 meters above sea level (Truman, 2001). The area had high rainfall in the period of November to June, while the dry season took place in July to October (Truman, 2001). The mean temperature was in the range of 25 ${ }^{\circ} \mathrm{C}$ to $27{ }^{\circ} \mathrm{C}$. The maximum temperature was $27.5^{\circ} \mathrm{C}$ that took place in October, while the minimum temperature was $26.5{ }^{\circ} \mathrm{C}$. The annual rainfall was 2.665 mm (the Government of Barito Kuala distrik, 2010).

Tumbang Samba was an important economic center, especially for the people living in Hulu Katingan. Actually, the area was administrtatively part of Central Katingan subdistrict consisting of four villages, which were Samba Danum, Samba Bakumpai, Samba Katung and Samba Kahayan. Based on the data of the Central Bureau of Statistics of Katingan district the population of Tumbang Samba was more than 13,000 individuals or almos a half of the total number of the population of Central Katingan subdistrict. It was in the capital city of the subdistrict that the daily economic activities of the upper course areas of Katingan took place. Tumbang Samba market as economic center not only provided local people with vegetables and groceries, but also other products such as agricultural tools, fishery tools, gold mining tools, and houshold equipments. Part of the upper course areas of Tumbang Samba could be reached using ground transportation means such as two-wheels vehicles and four-wheels vehicles, while the remaining areas could only be reached using water transportation means such as motorized boats or canoes called Kelotok.

The first migration of Bakumpai people to Tumbang Samba took place in 1900s. Datu Hajan along with his wife Datu Munah from Marabahan worked as rattan and latex gatherers. They built a raft from logs on which they build a house that was referred to as Lanting. They lived in the Lanting on the riverbank. The second migration that took place gradually continued and developed the skills of Bakumpai people in agriculture and fishing. Ninety percent of the population of Tumbang Samba was Moslem. They brought the custom and the culture from their place of origin such as Batatamba, Badewa and Batatenga ceremonies. In addition to do trading, Bakumpai people also did also missionary endeavor and religius proselytizing.

Long Iram and Bakumpai people was in an important economic phase of Mahakam River of East Kalimantan during the golden era of forest products in 1960s. The developmen of Long Iram kampong was dominated by agricultural activities of growing second crops such as rice, cocoa, corn with rainfed irrigation.

Long Iram kampong was geographically situated alongside Mahakam River representing water transportation line of boats, canoes and Ketinting for human passangers and cargos. Arable lowland was very good for agricultural development. Local transportation operated very good because the roads in Long Iram kamong were very good and connected to other villages. It had also easy access to Tering and Long Bagun subdistricts.

Haji Anjang was the third generation arriving in Long Iram. According to the local people the migration of Bakumpai people to Long Iram took place because of the war in the upper course of Barito River. They used North Barioto and South Barito migration lines to move eastward to Long Pahangai and Long Bagun. Also, the migration occured because of the presence of logging companies in the upper course of Mahakam River and many Bakumpai people found jobs in the companies. Just as the case of Dayak Bahau, Bakumpai woman named Ni Galung in Long Iram said that they came to Long Iram as traders, ratan and resin gatherers. And then, they began to settle in Long Iram as farmers and rubber tappers.

\section{The Ecological Condition and the Area of Study:}

The ecological condition of the lowland fitted the way of life of Bakumpai people in Ulu Benteng. The important thing was that Bakumpai people had close relationship with the ecological condition of the surrounding areas of the settlement, especially the importance of Barito River in their daily life. In this context Nasrullah (2007) found that the understanding of the ecology of Bakumpai people could be seen in their knowledge of seasonal circulation. They called wet season wayah danum and dry season wayang pandang.

For Bakumpai people, seasonal circulation consisted of four elements: 1) bulan kapat, 2) danum suhu, 3) danum bangai and 4) tayap. The term bulan kapat referred to the shifting dry and wet seasons, while the term danum suhu meant the wet season in the upper course areas of Barito River that caused flood in the estuary of the river. In such natural condition, Bakumpai people believed that there would be outbreak of diseases coming from the upper course areas of Barito River along with the river flow and reached the areas alongside the estuary.

The seasonal circulation also influenced the ecology of Barito River. Therefore, there was natural occurrence of danum bangai in which the water of the river became muddy with stink odor because of the increase in the mud content of the water mixed with brackish water (tayap). Tayap was sediment materials consisting of litter of dead grass, rotten leaves, branches and twigs on the river floor. Danum bangai and tayap resulted in the death of fish because of the toxic tayap water.

Bakumpai people believed that the condition of Barito River was not good for the people alongside the river. The natural change of hot and cool might be observed in the surrounding environment. The ecological condition of Barito River related to the occurrences in Safar month in which people living in the upper course of the river released poison or umpan into the river in a black magic release ceremony. 
Citation: Setia Budhi. Rain, River and Religion A Study of Negotiating Identity of Bakumpai People in Kalimantan, Indonesia. Australian Journal of Basic and Applied Sciences, 12(9): 26-30. DOI: 10.22587/ajbas.2018.12.9.4

\section{The Origin of Bakumpai People:}

Riwut (1993) suggested that Bakumpai people consisted of 7 big groups: (1) Dayak Ngaju, (2) Dayak Apu Kayan, (3) Dayak Iban and Heban or Dayak Laut, (4) Dayak Klemantan or Dayak Darat, (5) Dayak Murut, (6) Dayak Punan, and (7) Dayak Ot Danum. Dayak Ngaju consisted of four big ethnic groups: Ngaju Ma'anyan, Lawangan and Dusun. According to Riwut, Bakumpai people was classified into the family of Dayak Ot Danum consisting of 68 small ethnic groups such as Ngaju, Kapuas, Kahayan, Katingan, Sampit, and Seruyan.

However, there was another description that Bakumpai people was part of Dayak Ngaju or Dayak Ot Danum. The terms On Danum and Ngaju referred to hulu air or hulu sungai, upper course of a rever, meaning that they lived in the upper course areas of the river or udik, inland people. Meanwhile, Ngaju came from the word Bi-aju that meant inland people or Udik. Therefore, Ot Danum and Ngaju were of the same meaning, which was those living in the upper course of the river. Riwut suggested that based on the living areas of Bakumpai people, they originated from Dayak ethnics representing a big group of Ngaju and Ot Danum.

A historical satudy of Tumenggung Dayak in the area of Barito River has been conducted by Sjamsuddin (2001) in which there was some who stated that there has been Islamic proselytizing among Dayak ethnics at Central Kalimantan in $17^{\text {th }}$ and $18^{\text {th }}$ centuries. The study put the Dayak Bakumpai ethnics in the proselytizing activities in inland areas of Kalimantan. Sjamsuddin categorized Bakumpai people as Dayak serving as cultural intermediary of Malay and Dayak. He concluded that Bakumpai people originated from Dayak Ngaju that had relationship with Malay people in the coastal areas of South Kalimantan.

According to Setia Budhi (2000) Bakumpai people was classified into the family of Ot Danum as one of sub-Ngaju ethnics that was believed to have their origin in a village named Bakumpai of the upper course of Barito River. They migrated to South areas, including Basahab kampong, Saka Kampeng and Simpang Arja in the lower course of Barito River of Barito Kuala district of South Kalimantan.

According to Sellato (2000) the people living in the inland areas of Central Kalimantan and Dayak Ngaju people who were called "Biaju” in the areas of Barito River used the same language. The words Ngaju and Biaju were used to name the ethnic groups living in the upper course areas of Kahayan River and Barito River.

Biaju people were actually Ngaju people and one of the sub-ethnic groups was Bakumpai people. Sellato considered the dialect of Ngaju languate as the same with the one used in the areas of Kahayan, Katingan and Barito. The language served as intermediary languate (lingua franca) among the peoples of Central Kalimantan and South Kalimantan. The same language was also used by Bakumpai people, meaning that they originated from Dayak Ngaju.

In other part of his work Sellato (2000) suggested that it was expected that Bakumpai people came from Central Kalimantan and have lived in the areas alongside Ratah River for long time. Ratah River was a river in the areas of Mahakam River of East Kalimantan. Sellato suggested that Bakumpai people represented Dayak community that has converted into Islam. It showed that the origin of Bakumpai peole was Dayak Ngaju who has converted into Islam. In other words, Bakumpai people were Dayak Moslem.

One of the methods to the origin of Bakumpai people related to Dayak Ngaju was to see the aspects of their belief, especially those related to various rituals for therapy. One of the traditional therapies was badewa mananamba ceremony that involved the belief in spiritual beings. Therefore, Kloke (1988) studies the rituals for the therapy in Dayak Ngaju and suggested that the badewa ceremony used the same offerings as those used by Dayak Ngaju in balian ceremony for the purpose of therapy in Central Kalimatnan. The rituals in the traditional therapy organized by Bakumpai people were the evidences that the Bakumpai people originated from Dayak Ngaju and Ot Danum living in Central Kalimantan.

The description and the understanding of the origin of Bakumpai people were related to how and where the background and the origin of Bakumpai people and it might give the closest interpretation of the origin and the custom and the culture of the people. During my journey and based on my literature study I found that the opinion of experts in Bakumpai people on their origin was similar. They considered that the origin of the people was Dayak Ngaju. I began the description of the origin of the Bakumpai people with the term Bakumpai and then the perspective of the origin of Bakumpai people.

My main informants described that generally the term Bakumpai referred to three opinions. First, Bakumpai came from the name of a plant Kumpai growing alongside Barito River. Sedond, it came from the name of the predecessors of Bakumpai people, which was Datu Pandung Kumpai Duhung. Third, it came from the name of a headman Datu Bi-Yatu and Bi-Yulu. The three opinions have always been being interesting ones.

However, there were also various perspectives in the writings of the origin of Bakumpai people, which seemed to relate to the community living and had the origin in the upper course of Barito River that was called Oloh Ngaju.

Schwaner (1853) who has organized geological expedition in Barito River suggested that Marabahan and Muara Bahan ports repres ented lively commercial center for those living in the areas alongside Nagara River, Kapuas River and Kahayan River at that time. Therefore, the settlement areas of Bakumpai people were situated in the Marabahan port representing the important commercial center for inland Dayak people and Malay people living in costal areas. The Marabahan port was transshipment for commercial ships. He suggested that Bakumpai people has spread Islam since 1688. Though he did not know Bakumpai language, he considered the language as different from Banjar Malay language. There were many vocabularies in Bakumpai language indicative of the origin of Bakumpai people, which was Dayak Ngaju.

Scharer (1963) categorized the group of Dayak Barito as Ngaju. The term Ngaju in the local language meant "ke hulu”, toward the upper course. Additionally, there was also the term "Ngajus" to identify the group as "Oloh Tumbang" representing the community of Dayak who lived in the areas alongside the estuary. Olong Tumbang people lived alongside the estuary of Barito River and it referred to the community of Bakumpai people.

Based on the study of Bakumpai people and considering ethno linguistic aspect Ibrahin (1978) concluded that Bakumpai languate used by the people of Barito Kuala district was indicative of the origin of the Bakumpai people, which was Dayak Ngaju (Ngaju Isolect). Rahmi (1987) in her study of the religion and the belief of Dayak Bakumpai suggested that the majority of their religious ceremonies were influenced by Melayu Banjar culture. Hudson (1967) also had the same opinion. He related the language to the languages used in the areas of Central Kalimantan, especially those spoken in the areas alongside Barito River, which was "Barito Isolect". The isolect was spoken by almost 350,000 Bakumpai people in the areas alongside Barito River.

\section{Social and Cultural Bond:}

Social relationship was considered as cultural institution of a society in which individual members of the society supported each other, were in mutual trust, and cooperated with each other on voluntary basis. The social relationship represented non-economic capital of the society in developing strong community and in settling horizontal violent conflicts, in solving criminality problems, and in maintaining the sustainability of the society. It was inclusive and able to overcome individual and group narrow interests.

The inclusive social relationship was more likely to develop in rural areas with homogenous and religious societies that upheld communal principles and social protection for the members of the societies. Such rural areas had inclusive social relationship because of the homogeneous characteristics of their members and based on the social system representing the extension of familial system.

Therefore, there were many families in rural societies that still had cognation relation or inter-familial marriage relation. It was the social relationship that became the basis of the rural societies. Essentially, rural society was more homogeneous in ethnical and religious identities and consisted of interrelated families. Bakumpai people in Ulu Benteng comprised the same ethnics. The inter-familial social relationship in neighgorhodd environment was based on the traditional value of community togetherness. The relationship was more emotional in nature and based on traditional principles and beliefs. It seemed that the communal familial entities reconstructed themselves based on the basic traditional relationship and beliefs into ethnic-religious community.

Social Relationship Reconstruction:

The reconstruction of the inclusive social relationship was the response to the dynamics in the rural life that was essentially cohesive and avoided conflicts. The growing inclusive ethnic-religious social relationship represented the social, cultural and familial instruments to achieve common objectives. The inclusive social relationship enabled individuals to position themselves among other individuals and neighbors of the same ethnic-religious roots as "a family". Daily greetings might serve as emotional relationship. Individuals involved in communal activities because the communal activities brought them into seamless togetherness and cohesion. 
Citation: Setia Budhi. Rain, River and Religion A Study of Negotiating Identity of Bakumpai People in Kalimantan, Indonesia. Australian Journal of Basic and Applied Sciences, 12(9): 26-30. DOI: 10.22587/ajbas.2018.12.9.4

On the contrary, Diane E. Davis in Cities and Sovereignty: Identity Politics in Urban Spaces (2011) warned that urban society with exclusive social relationship construction on ethnic-religious basis was essentially fertile soil for identity politics. The society was composed of the relationships that have been politicized by the exclusive social relationship. Each relationship was built in a social environment that was not "honest" and even created escalating violence and criminality in every urban corner. Bakumpai people in Ulu Bentenga kamong took the honest and familial position in organizing their social, cultural and customary activities.

The social relationship of a society experienced social transformation into the one capable of mutual cooperation and care in homogeneous environment of the same ethnic-religious community. Leadership in each of the social structure level should be able to motivate. Social relationship enabled the development of socially inclusive society in the familial categories below.

\section{Hakula:}

Hakula came from the word Kula that meant family. $\mathrm{Ha}$ was a prefix that changed the stem Kula into adjective. It was typical social construction of Bakumpai people that enabled the conservation of familial relationship both in nuclear family and in extended family. Hakula as part of the weltanschauung of the Bakumpai people put the emphasis on the principle of genealogical relationship of the people that was transferred into cultural context. Based on the spirit of Hakula Bakumpai people could adapt to almost any social, ethnic and religious environments. They left their village and moved to other areas for the reason that they would like to see other people they identify as Kula.Hakula in its familial form was plural and referred to as Kula Biti. Kula Biti referred to wider familial relationship.

Anjang Hasan, one of the informants of the study coming from Long Iram village alongside Mahakam River of East Kalimantan said, "In the past I lived along with my parents who worked as "mengguling batang" in Mahakam that was still dense forest and there were many family members followed me working in the forest. We could do marengge, marawai and mauntang-untang as we did in our kampong Basahab Barito Kuala. I felt home here and considered the place as my own kampong and I considered the villagers in the kampong as Kula and even more than Kula because they were the closest ones than my relatives in my original kampong."

Handep:

The survival spirit of Bakumpai people in other land where they made a living was inseparable of their social and cultural network. The majority of Bakumpai people upheld the familial culture and the social system of Kula Biti. The word Handep might be considered as the synonym of together or along with. The word Handep might be understood as doing something together. So, it meant active participation of each individual in creating positive added-value to the effort to satisfy common needs in a society. The active participation might be manifested in financial support, physical labor, skills, constructive idea contribution to the organization of communal life.

Conceptually, handep might be considered as cooperation model on common agreement. In socio-cultural perspective, the value Handep represented a spirit as manifested in individual behavior and actions that were collectively done for no expectation of any reward, but for both collective and individual interests. The activities in the spirit of Handep might be manifested in mutual help in agricultural areas.

The terms Hakula and Handep represented local wisdoms and local knowledge or local genius. The local wisdom meant the weltanschauung and the knowledge as living strategy in dealing with various problems in social life, including the problem in satisfying common needs. The system in satisfying common needs included all aspects of life, including religion, science, technology, social organization, language and communication and also arts that might be manifested in tradition, aphorisms or living catchword. Then, the system became the way of life of Bakumpai people.

\section{Dayak-Malay Negotiation:}

Ethnicity was primordial in nature and it was not debatable. However, there was a consensus that ethnics provided people with meaning, identity, and community. Even, ethnics were defined on the basis of the ideas of groups of various cultural identities, languages, and their origin.

On the contrary, Benedict Anderson (1983) suggested that ethnicity was imagined because the members of the collectivity may never know most of their fellow members or share with them interpersonal relations and may not even hear of them, but the image of their close association lives in the mind of every member. This image of close association may be created through media messages, which try to convince people by explaining them about the community sharing origins, traditions, and common goals. The primordial relationship among Bakumpai people has been constructed in very long period of time. They have proven their strength and tenacity in maintaining their language and tradition not only using adaptation, but also using negotiation.

Considering the function of the ethnicity and the beliefs as inseparable of the ethnic group could result in strong and cohesive construction. As strong social adhesive, ethnic organization enabled individuals to find Bakumpai people developing their local and universal ethnical identities.

At first glance, ethnicity was a straightforward concept. However, on closer examination, it was subject to different interpretations. Essentially, ethnicity was a sense of identity. It could incorporate several forms of collective identities, including linguistic, religious, caste, and regional forms. According to Philip Q. Yang, "ethnicity might be defined as an affiliation or identification with an ethnic group. Other synonyms of ethnicity included ethnic group membership, ethnic affiliation and ethnic identity" (2000: 40). In other words, ethnicity was a sense of belonging to a particular ethnic group and that belongingness might be based on characteristics such as physical attributes, presumed ancestry, culture, or national origin. Ethnicity focused on cultural differences, and it covered and accommodated religious groups, regional demarcations, and linguistic segregations.

Until 1960, the notion of ethnicity was not prevalent in anthropological usage. The first decisive text in anthropology on ethnicity is Fredrik Barth's Ethnic Group and Boundaries (1969b as in Jenkins 1997). Barth began with the thought that an actor believed in ascription and self-ascription. He did not focus upon the cultural characteristics of ethnic groups but upon relationships of cultural differentiation and contact between the collectivities, which differentiated "us" from "them" (Eriksen in Jenkins, 1997). The point was that identity was generated, established, or changed in the course of interaction (Jenkins, 1997). Richard Jenkins (1997: 40) has spelt out a basic anthropological model of ethnicity.

It seemed that the negotiation and the identity among Bakumpai people were consistent with the model that consisted of four propositions: 1 . Ethnicity emphasized cultural differentiation (although identity was always dialectic between similarity and differences, 2. Ethnicity was cultural-based in shared meanings, but it was produced and reproduced in social interaction, 3. Ethnicity was to some extent variable and manipulable, not definitively fixed or unchanging, and 4 . Ethnicity as a social identity was collective and individual, externalized and internalized.

\section{Closing:}

Bakumpai people were Dayak ethnics who lived alongside Barito River, Katingan River and Mahakam River. The majority of them were Moslem. Considering their strategic geographic position in South Kalimantan, Central Kalimantan and East Kalimantan, the Bakumpai people have been playing an important role in spreading Islam in Kalimantan.

The existence of the Bakumpai people was inseparable of their unique culture and their capability to integrate themselves to other ethnic and religious groups. The harmonious integration enabled them to lead "balanced life". Therefore, it was hard to find them in serious conflict against other ethnic groups from the past time to the present time. It was part of their negotiating capability with other ethnic groups to maintain their life in development and modernization process.

Though the Bakumpai people had close relationship with Malay Sultanate of Islamic Banjar, they also developed cohesiveness with other communities of Dayak living in inland areas of Kalimantan. Moslem Bakumpai absorbed the cultural elements of Malay Banjar in maintaining social and cultural traditions and beliefs.

\section{REFERENCES}

Appell, G.N., L.R. Wright, (pnyt.), 1978. The status of social research in Borneo. Ithaca : SEA Program, Cornell University. 
Citation: Setia Budhi. Rain, River and Religion A Study of Negotiating Identity of Bakumpai People in Kalimantan, Indonesia. Australian Journal of Basic and Applied Sciences, 12(9): 26-30. DOI: 10.22587/ajbas.2018.12.9.4

Ave, J.B., V.T. King, 1986. The people of the weeping forest, tradition and change in Borneo.Leiden : National Museum of Ethnology.d\%20Syadzalidoc di aksestanggal 6 Juni 2007.

Bernstein, J.H., 1997. Spirits captures in stone. shamanism\& traditional medicine among the Taman of Borneo. USA : Lynne Reinner Publishers, Inc.

Chalmers, I., 2006. The Dynamic of confersion: the Islamisation of the Dayak Peoplesof Central Kalimantan. makalahdalamConferensi the Asian Studies Association of Australia (ASAA) di Wollongong, 26-29 Juni: http: //coombs.anu.edu.au/SpecialProj/ASAA/biennialconference/2006/Chalmers-IanASAA2006.pdf.

Collin, J.T., 2003. AlamMelayudanmasyarakatEmbau.DlmYusriadi\&Hermansyah (pnyt.). Orang Embau: Potretmasyarakatpedalaman Kalimantan. STAIN Pontianak, Adikarya - Ford Foundation.

Dalmatius Madrah, 1997. Lemu:Ilmumagissuku Dayak Benuaq \& Tunjung. Jakarta :Puspa Swara.

Dillistone, F.W., 2002. The power of symbols. Yogyakarta: Kanisius.

Geertz, C., 1960. The Religion of Java.Chicago : The University of Chicago Press.

Geertz, C., 1973. Interpretation of cultures. New York: Basic Books, Inc.

Gimlette, J.D., 1971. Malay Poisons and charm cures. Kuala Lumpur : Oxford University Press.

Hashim Awang, A.R., 2012. Strukturalimesatutunjauandarisegiteoridanapplikasi. http/www/eprints.um.edu.my/659. 28 desember 2013.

Haron Daud, 2002. ManteraMelayu: analisispemikiran. Pulau Pinang: Penerbit University Sains Malaysia.

Haliza MohdRiji, 2000. Prinsipdanamalanperubatan Melayu. Kuala Lumpur :Dewan Bahasadan Pustaka.

Haron Daud, 2004. Ulitmayang: kumpulanmantera Melayu. Kuala Lumpur: Dewan Bahasadan Pustaka.

Haris, M., 1972. The rise of anthropological theory. London: Routledge \& Kegan Paul.

Hermansyah, 2003. IslamisasipedalamanKalimantan Barat: Kajianatasperan Islam sufistik. Kertaskerja yang dibentangkanpada seminar LEPAS, Pontianak,

Indonesia, $25 \mathrm{Mac}$.

Hope, M., 1997. ILMUMagic and divination among The Banuaq and TunjungDayak.Jakarta: PuspaSwara.

Hudson, A.B., 1967. PadjuEpat: the Maanyan of Indonesia Borneo. New York: Holt, Rinehart and Winston.

Jensen, E., 1974. The Iban and their religion.Oxford : Clarendon Press.

Karim, A., 2003. Shamanism in Bangladesh.Dlm. Clark Chilson and Peter Knech. (pnyt) Shaman in Asia page. 51-82. London :Routlege Curzon.

King, V.T., 1978. Essays on Borneo societies. Hull Monographs on Southeast Asia No. 7. Oxford: Oxford University Press.

King, V.T., The Maloh of west Kalimantan. USA: Foris Publications, Dordrecht-Holland/Cinnaminson-USA.

Kimball, L.A., 1979. Borneo medicine: the healing art of indigenous Brunei Malay medicine. Ann Arbor-Mich: Published for the Anthropology Department,

Loyola University of Chicago by University Microfilm International.

Laderman, C., 1991. Taming the wind of desire: Psychology, medicine, and aesthetics in Malay shamanistic performance. Berkeley: University of California Press.

Levi-Strauss, C., 1966. The Savage Mind.Chicago : The University of Chicago Press.

Lévi-Strauss, C., 1969. The Elementary structures of kinship. Great Britain: Eyre \&Spottiswoode (publisher) Ltd.

Lieban, 1926. Dlm, G.M. Foster, B.G. Anderson, 1978. Medical Antropology. New York. John Wiley \& Sons.

Middleton, John (pnyt.), 1967. Myth and cosmos. New York: The Natural History Press.

Nasrulah, 2007. Ngaju, ngawa, ngambu, liwa :analisisstrukturalismelévi-straussterhadapkonsepruangdalampemikiran orang dayakbakumpai di sungaibarito. Antropologi, Universitas Gadjah Mada.

Nieuwenhuis, A.W., 1994. Di pedalaman Borneo: Perjalanandari Pontianak keSamarinda. Terj. Theresia Slamet \& P.G. Katoppo. Jakarta: Gramedia

Pustaka Utamadan Borneo Research Council.

Noried Haloi Radam, 2000. Religi Orang Bukit, suatulukisanstrukturdanfungsidalamkehidupnsosial-ekonomi. Yogyakarta: YayasanSemesta.

Ras, J.J., 1968. HikajatBandjar, a study in Malay Historiography. The Hague-MartinusNijhoff.

Rassers, W.H., 1959. Panji, the culture hero.a. structure study of religion in Java. The Hague-MartinusNijhof.

Rousseau, J., 1998. Kayan religion: ritual life and religious reform in Central Borneo. Leiden : KITLV Press.

Rousseau, J., 1990. Central Borneo: Ethnic identity and social life in a stratified society. Oxford: Clarendon Press.

Schwaner, 1853. Borneo.Beschrijving van het stroomgebied van den Barito en reizenlangseenigevoornamerivieren van het zuid-oostelijkgedeelte van dateilanddoor Op last van het gouvernement van Nederland: Indie gedaan in de jaren 1843-1847.

Schadee, M.C., 1979. Kepercayaansukudayak di Tanah LandakdanTayan. Jakarta: YayasanIdayu.

Schrer, H., 1963. Ngajureligion: The conception of god among a South Borneo people. The Hague: MartinusNifhoff.

Schiller, A., 1997. Small sacrifices: Religious change and cultural identity among the Ngajuof Indonesia. Oxford: Oxford University Press.

Sellato, B., 1992. Hornbill and dragon.Kalimantan, Serawak, Sabah and Brunei. Jakarta and Kuala Lumpur: Elf Aquitaine.

Sellato, B., 2000. Innermost Borneo: Studies in Dayak culture. Paris: Seven Orients \& Singapore University Press.

Shamsul Amri Baharuddin, 2000. Pembentukanidentitisebagaifenomenasosial: suatupertimbangankritis. Setiawacana 11.Sabah :UniversitiKebangsaan Malaysia. Sabah.

Tsing, A.L., 1993. In the realm of the diamond queen: Marginality in an out of the way place. Princeton: Princeton University Press. 